\title{
Awakening the Biodiversity Potential trough ST\&I Investments in the Sector of Amazonian Biotechnology
}

\author{
Fabiana dos Santos e Souza Frickmann',Alexandre Guimarães Vasconcellos²
}

\begin{abstract}
The biotechnological development conciliated to Amazonian biodiversity represents a big potential for richness to Brazil. This study analyses the Brazilian investments in ST\&I Amazonia's, utilizing as indicator for that, the resources applied in R\&D and the patent appli;cations coming from Amazon, which were filed with the National Institute of Industrial Property during the period from 2003 to 2008. The objective is to analyze how where such investments applied by the Ministry of Science, Technology, and Innovation (MCTI), and which was their impact over the biotechnological inventions of Amazonian origin. In the results, we observed that R\$1,308.09 million was invested in ST\&l in Amazonia. The Amazonian state that attracted the larger part of such resources was Amazonas and 153 patent applications were identified as coming from the state of Amazonas; out of which, 56\% derived from companies of the Manaus Industrial Pole, and $9 \%$ originated from biomedical and alimentary sectors.
\end{abstract}

Keywords: Brazil; amazonia; public investments; biotechnology; patents; science, technology and innovation (st\&i); research and development ( $\mathrm{r} \& \mathrm{~d})$; innovation; amazonian bioproducts; sustainability.

\footnotetext{
'PhD by the 'Program of Vegetal Biotechnology' of the Federal University of Rio de Janeiro (UFRJ). Researcher in the 'Biodiversity and Health Management Nucleus' (NGBS), Farmanguinhos/Fiocruz. Personal Address: Rua Mearim, 26I, AP. 202, Grajaú, Rio de Janeiro, Brazil, ZIP code: 2056I-070, Phone: 2 I 98506570, 2 I 2577-2628. E-mail: fasect@yahoo.com.br

${ }^{2}$ Researcher in Industrial Property of the 'National Institute of Industrial Property' (INPI) and Permanent Professor of the 'Academy of Intellectual Property and Innovation' of INPI.
} 


\section{Introduction}

Modern world is configured full of investments opportunities, facing a situation of economic crisis (Krugman, 2009), exhaustion of cultivable soils, global warming, greenhouse effect, and decrease of freshwater in the terrestrial environment. In this perspective, Amazonia is strongly focused as natural stock of carbon and prioritized conservation area. For this reason, Brazil is receiving financial incentives from developed countries, such as Norway and Germany, through the Amazonia Fund, launched in 2009 to facilitate the sustainable development of region (http://www.fundoamazonia. gov.br/FundoAmazonia/fam/site_pt/Esquerdo/Doacoes/, accessed on April 3rd, 2009).

It is difficult to accurately quantify the value of the Amazonian "El Dorado". The process of valuation of this ecosystem passes by several types of comprehensions and marketing interests (Abalgli, 200I). For the biotechnological [According to Organization for Economic Cooperation and Development (OECD), biotechnology can be defined as the application of science and technology to live organisms, as well as their parts, products, and models, to alter living and nonliving materials for the production of knowledge, goods, and services] sectors, it represents a very important source of raw material and knowledge. This, because large part of the genetic diversity contained in this ecosystem remains unexplored for many species, presenting promising perspectives for bioprospecting.

On the other hand, several studies (Frickmann \& Vasconcellos, 2010; Becker, 2009a' Enríquez, 2009;Arruda, 2009; Costa, 2009; Homma, 2008; Revilla 2007; Di Stasi, 2005; Gottlieb \& Borin, 2002; Brasil/PAS, 2008; Brasil/MAPA, 2009) indicate that in order to assure the environmental sustainability of Amazonia, it is necessary to ensure the socioeconomic development of local population. In this feature, biotechnology is stimulated in order to aggregate value to products derived from flora and fauna, using the knowledge from local populations. The purpose is to provide the expansion of sectors that make better use of the region natural vocations, such as those of: phytopharmaceutical and phytotherapeutic agents, biocosmetic and dermocosmetic agents, nutraceutical and biotechnological products, between others using the regional plant supplies.

It is furthermore necessary to improve the mechanisms of financial compensation, as for the actors involved in the long production chain [Normally originating from Extraction Reservations (REServas EXtrativistas - RESEXs) inside the Amazonian Forest], as for the cost of transportation and taxes charged in the marketing process. Besides, there is a serious asymmetry of availability of human resources specialized for research and development (R\&D) activities at
Amazonia, respecting to remaining parts of the country. This fact generates deep reflexes for the development of a science, technology, and innovation ST\&I culture in the region. This is because the number of doctor graded individuals in Brazil, in 2008, corresponded to 87,063 (Brasil, 2010); out of which, only $5 \%$ were effectively working in the Brazilian Amazonian region (Frickmann \& Vasconcellos, 20I I). Being that such region comprises more than $59 \%$ of the Brazilian territory. The Brazilian Law of Innovation (Law \# 10973, of December 2nd, 2004), by means of its Art. 27, assumed the national commitment to "prioritize actions in the less developed regions of the Country and Amazonia, aiming to endow the investigation and regional productive system with larger human resources and technological capacity", to help innovation.

Hence, Brazil has matured scientifically and technologically, creating several policies for incentive to innovation and biotechnology. In the federal sphere, the research, development, and biotechnological innovation (RD\&l) activity has been funded by Brazilian organs, such as: the Studies and Projects Funder (Financiadora de Estudos e Projetos - FINEP), the National Council for Scientific and Technological Development (Conselho Nacional de Desenvolvimento Científico e Tecnológico - CNPq), the Coordination for Improvement of Higher Education Staff (Coordenação de Aperfeiçoamento de Pessoal de Nível Superior - CAPES), and the National Bank of Economic and Social Development (Banco Nacional do Desenvolvimento Econômico e Social - BNDES). In the regional plan, the funding takes place by means of the Bank of Amazonia (Banco da Amazônia S.A. - BASA), and Foundations for Support to Research (Fundações de Amparo à Pesquisa - FAPs), linked to State Secretariats of the different Amazonian Governments.

So, prepared extracts, isolated active principles, and Amazonian biotechnological inventions, founded and developed in the Country, within Universities and Public Institutes, and derived from the biodiversity, are achieved and intellectually protected. The main forms of intellectual protection utilized are as follows: patents (Homma, 2008), geographical indication - Gl (Lima et al. 2007), certificate of cultivar variety protection (Santilli, 2005), trademark (Moreira \& Mileo, 2003), and/or industrial design (Clement \& Higushi, 2003). Such items, after protected, can be commercially explored, being definitively inserted in the regulated market, in a more competitive way.

The companies that develop the inventions generated in the universities and protected by the Technological Innovation Nuclei (Núcleos de Inovação Tecnológica - NITs) pay royalties, and can also pay benefit sharing for the traditional populations, as determinated by Provisional Measure \# 2186/16, of 2001 .

ISSN: 07 I8-2724. (http://www.jotmi.org)

Journal of Technology Management \& Innovation (c) Universidad Alberto Hurtado, Facultad de Economía y Negocios. 
It is important to emphasize that, as a result of globalization, the market of Amazonian natural products is achieving millionaire and growing expectations. However, Brazil is in discrepancy respecting to biotechnology market, which is progressively warming since the decade of 90 's. The countries leading this sector are located in Europe, Asia, and North America. Such countries have opened up the market of modern biotechnology, creating and developing 4,284 companies focused on new industrial applications (Silveira \& Borges, 2004). In the new millennium, this technology creates new market niches and industrial investment opportunities in the developing and megadiverse countries, such as: Brazil, India, and China.

Silveira et al. (2007) describe that the difficulty of entrepreneurship in the sector of biotechnology is a fact of modern world, which alters the own grounds of companies constitution, redesigning their limits and those of their markets, restructuring them over new economic and institutional bases. The authors denominate this form of organization as sectorial system of biotechnological innovations. The components of this system are the biotechnology companies, their suppliers, their clients, the aggregate of government research laboratories, the individual agents, and the organizations in which the biotechnology firms maintain long term contractual relationships.

This study investigated if Brazilian government is aware of the Amazonian potential for biotechnological development, and how it is investing in ST\&l, to promote such innovations in the Brazilian Amazonia.

\section{Objective}

This work investigated if the investments in ST\&I coming from the Ministry of Science, Technology, and Innovation (Ministério da Ciência Tecnologia e Inovação - MCTI) and addressed to Brazilian Amazonia were, effectively, converted into biotechnological inventions in the health area.

\section{Specific Objectives}

I.To raise and analyze the Brazilian investments in ST\&I that were developed in the Brazilian Amazonia, associating them to patent applications coming from the Amazonian State that attracted the largest financial assistance, during the period between 2003 and 2008;

2. To identify if there was conversion of such investments, into patent applications from the biotechnological or similar sectors.

\section{Methodology}

This study possesses as coverage area the 'Brazilian Amazonia' or 'Legal Amazonia', which is a territory including nine Brazilian states: Acre (AC), Amapá (AP), Amazonas (AM), Mato Grosso (MT), Pará (PA), Rondônia (RO), Roraima (RR), Tocantins (TO) and, partially, the State of Maranhão (MA) (to west of the meridian $44^{\circ}$ western of Greenwich), which is here included in its totality, for purposes of data collection; this territory includes a surface of approximately 5,217,423 km2 (Brasil/SUDAM, 20I0).

The resources destined by the Ministry of Science, Technology, and Innovation (MCTI) to the development of ST\&I in the Brazilian Amazonia, as well as the route coursed by such resources up to Scientific and Technological Institutions (Instituições Científicas e Tecnológicas - ICTs) [The definition given for ICT, according to Brazilian Law of Innovation \# 10973 (December 2nd, 2004), is "body or entity of the public administration that has as institutional mission, among others, to execute basic or applied research activities, with scientific or technological character"], were identified and analyzed.

The Amazonian State that attracted the larger part of the resources destined to ST\&I was selected, and the patent applications coming from this same State, and filed in the National Institute of Intellectual Property (INPI), were analyzed. This study considered the amount of patent applications as an indicator of Science, Technology, \& Innovation (ST\&I) activity, based on the Manual of Oslo ( 1997), http:// www.oecd.org/dataoecd/35/6I/2367580.pdf (accessed on July 5th, 20II).

According to item 6.I of the Manual of Oslo, "there are two basic families of indicators of Science and Technology (S\&T), which are of direct interest for the measurement of technological innovation, products, and processes (TPP): the resources dedicated to Research and Development (R\&D), and the statistics of patents".

\section{Resource dedicated to R\&D}

The following public Brazilian data were raised: (I) resources invested by the Ministry of Science, Technology, and Innovation (MCTI), under the form of scholarships, fomentation, sectors funds, units of research and social inclusion in the period of 2003 to 2008 [data provided by the Fund Raising Advisement (ASsessoria de CAPtação de Recursos - ASCAP) of the Executive Secretariat (Secretaria EXECutiva SEXEC) of MCTI (Brasil/MCT, 2009); (2) mapping of Amazonian FAPs by means of National Council of State Foundations of Support to Research (COnselho Nacional das Fundações Estaduais de Amparo à Pesquisa - CONFAP) (http://www.

ISSN: 07 I8-2724. (http://www.jotmi.org) 
confap.org.br); (3) documental search in the websites of the Amazonian FAPs and Amazonian State Secretariats; and (4) analysis of public edicts and/or support research programs utilizing the method of analysis of content (Bardin, 1977).

\section{Patents analysis}

Once identified the Amazonian State attracting the higher value of ST\&l investments allocated by the MCTI, the patent applications filed from such State were raised. The raising was done in the INPI [Instituto Nacional de Propriedade Industrial - INPI / Brazil] database, using the following categories: Invention Patent (Patente de Invenção - PI), Utility Model (Modelo de Utilidade - MU), and Addition Certificate (C). The search for patent applications was developed by means of a documental investigation, which took place at the INPI public database (www.inpi.gov.br), in November 2009. The period analyzed was between 2003 and 2008, and all patent applications of the State of Amazonas were raised and categorized, based on technological fields of the International Patents Classification (IPC). The methodological scheme of investigation is represented at Figure I.

\section{Results \& discussion}

In the period of 2003 to 2008, several Laws and National Programs were created for the Brazilian Amazonia, according to figure 2. In the Brazilian Amazonia, or legal Amazonia, the total of ST\&I investment corresponded to I,308.09 million of Reais ( $R \$)$ [R\$2 = US\$ I] (MCTI Source). The total of investments in science and technology, per Amazonian State, are described in millions of Reais, in ascending order: Amapá = R\$12.12; Roraima $=R \$ 19.19 ;$ Acre $=R \$ 22.72$; Tocantins = R\$29.79; Rondônia = R\$38.10; Maranhão = $\mathrm{R} \$ 46.30$; Mato Grosso $=\mathrm{R} \$ 63.43$; Pará $=\mathrm{R} \$ 334.25$; and Amazonas $=R \$ 741.86$. These values are graphically represented at Figure 3. In this way, we identify that the State of Amazonas attracted the larger public financial support in the period, followed by State of Pará.

This fact could be consequence of the maturity of the complex ST\&I System of the State of Amazonas, which is managed by SECT/AM since 2003 and funded by FAPEAM, its linked institution; being both administered by a regional team of qualified professionals (masters and doctors).

ST\&I investments destined to Brazilian Amazonia by MCTI

Selection of the Amazonian State attracting the larger part of resources destined by MCTI

\begin{tabular}{|c|}
\hline \multicolumn{2}{|c|}{$\begin{array}{c}\text { Raising of Patent Applications from the selected } \\
\text { Amazonian State }\end{array}$} \\
Trend for technological development of the selected \\
Amazonian State
\end{tabular}

Figure I: Scheme of the analysis method (period analyzed 2003-2008)

\begin{tabular}{|l|l|l|}
\hline$N^{\circ}$ & INSTRUCTION DEVICE & YEAR OF PUBLICATION \\
\hline I & Law of Industrial Property (\#9279) & 1996 \\
\hline 2 & Law \# 9985, instituting Extraction Reservations & 2000 \\
\hline 3 & $\begin{array}{l}\text { Provisional Measure (\#2 I86-16), giving access to national genetic patrimony and } \\
\text { associated traditional knowledge. }\end{array}$ & 200 I \\
\hline 4 & National Law of Technological Innovation (\# 10973) & 2004 \\
\hline 5 & Term of Reference of Support to Development of Local Productive Arrangements & 2004 \\
\hline 6 & Law of Innovation of Amazonas State (\# 3095) & 2006 \\
\hline 7 & National Law of Biosafety (\# II I05) & 2005 \\
\hline 8 & National Policy of Medicinal Plants and Phytotherapeutic Agents & 2006 \\
\hline 9 & $\begin{array}{l}\text { Industrial, Technological, and Foreign Trade Policy of the Federal Government } \\
\text { (Política Industrial,_Tecnológica e de Comércio Exterior - PITCE) }\end{array}$ & 2006 \\
\hline 10 & National Policy of Biotechnology & 2007 \\
\hline II & Bionorte Postgraduate Program & 2011 \\
\hline
\end{tabular}

Figure 2: Laws, Policies, Programs, and other instruments guiding the national biotechnological development, with emphasis in the Brazilian Amazonia.

ISSN: 07 I8-2724. (http://www.jotmi.org)

Journal of Technology Management \& Innovation (c) Universidad Alberto Hurtado, Facultad de Economía y Negocios. 
With nine years of existence, the FAPEAM is between the larger Brazilian FAPs, with one of the larger Brazilian values of scholarships to assist investigation and innovative edicts. The research scholarships are important vehicles for specialized human resources captation, of the type: graduate, masters, and doctors, for a given period, to develop specific projects. The research scholarships values represent strong attractive for just graduated young investigators with interest in the Amazonian ecosystem.

In the interval between 2003 and 2008, the FAPEAM invested around R\$159 millions in ST\&I (AMAZONAS/FAPEAM, 2009), constituting so, the main regional source of non-reimbursable public investments to scientific and technological research in areas characterized by the Plan of Action 2007$2010 / \mathrm{MCTI}$ as having "promising future".
These resources were destined to different institutions settled in the Brazilian Amazonia [Examples of ICTs settled in the Brazilian Amazonia are: the 'National Institute of Amazonian Research' (Instituto Nacional de Pesquisa da Amazônia - INPA), the 'Brazilian Company of Farming and Cattle Raising' (Empresa Brasileira de Agropecuária - Embrapa), the 'Foundation Oswaldo Cruz Institute' (Fundação Instituto Oswaldo CRUZ - FIOCRUZ), and the 'Tropical Medicine Foundation' (Fundação de Medicina Tropical - FMT), among others], by means of public edicts, such as, for instance: the Edict 00I/2007 - Manaus Free-trade Zone Authority (SUperintendência da Zona FRAnca de MAnaus - SUFRAMA) covenant for support of the Center of Biotechnology of Amazonia (Centro de Biotecnologia da Amazônia - CBA) and the Program for Support to Excellence Nuclei (PROgrama de Apoio a Núcleos de EXcelência - PRONEX). Part of

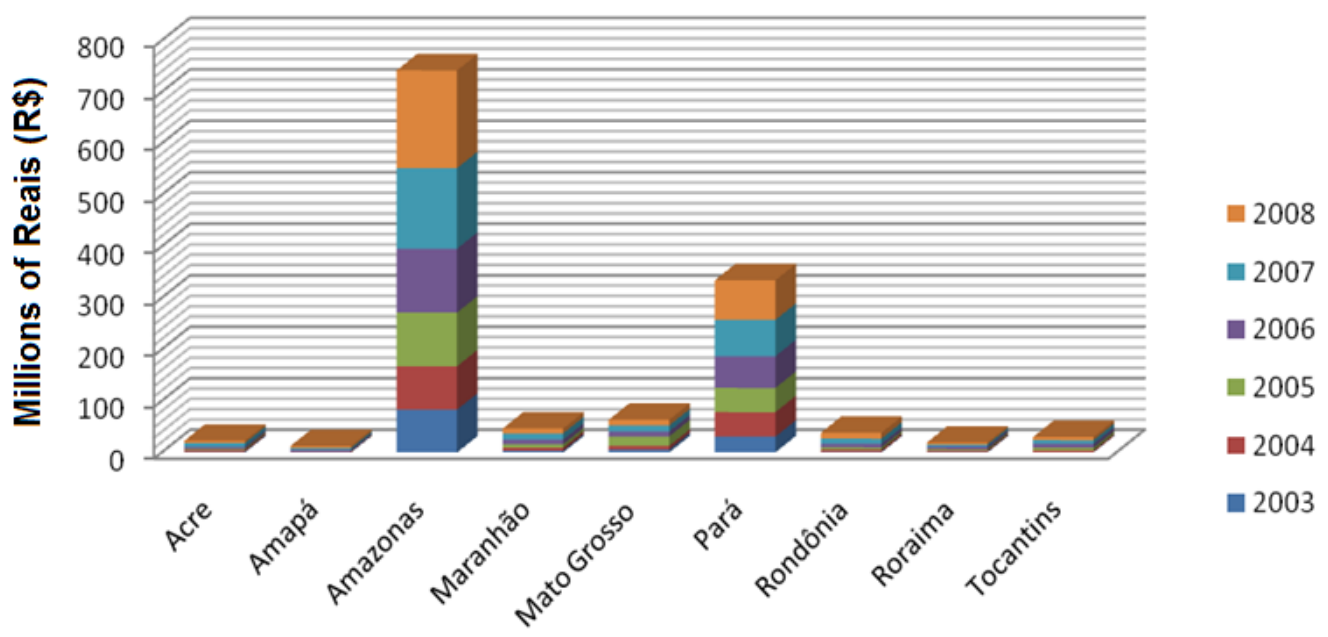

States of Legal Amazonia

Figure 3: Federal Investments (in order of millions of Reais) in ST\&l, destined to States of Brazilian Amazonia or Legal Amazonia, during the period between 2003 and 2008. (Data source Brasil/MCTI, 2009).

\begin{tabular}{|l|l|l|}
\hline STATE & FAP NAME & YEAR OF CREATION \\
\hline Acre & FUNTAC & 1997 \\
\hline Amapá & Fundação Tumucumape & 2010 \\
\hline Amazonas & FAPEAM & 2003 \\
\hline Maranhão & FAPEMA & 2003 \\
\hline Mato Grosso & FAPEMAT & 1997 \\
\hline Pará & FAPESPA & 2007 \\
\hline Tocantins & Fundação de Apoio à Pesquisa do Tocantins & 2011 \\
\hline Roraima & FEMACT ----------- & 2011 \\
\hline Rondônia & & ------ \\
\hline
\end{tabular}

Figure 4: Foundations for Support to Research Existing in the Brazilian Amazonian Region

ISSN: 07I 8-2724. (http://www.jotmi.org)

Journal of Technology Management \& Innovation (c) Universidad Alberto Hurtado, Facultad de Economía y Negocios. 
the resources was also destined to fund research networks, such as Geoma Network, which develops a 'Pilot Project of Environmental Modeling in the Region of the Arc of Deforestation' and the 'Biodiversity and Biotechnology Network of Legal Amazonia' (Rede de Biodiversidade e Biotecnologia da Amazônia Legal - BIONORTE), which signed a partnership between the MCTI, the CNPq, the State Secretariats of Science and Technology (Secretarias Estaduais de Ciência e Tecnologia - SECTs), and FAPs, in 2009. The FAPEAM has assisted in the process of organization and implementation of Amazonian FAPs. It has also stimulated the concretization of the FAPs of states of Tocantins, Amapá, and Roraima, which recently started to operate.

The Amazonian FAPs contributed for the decentralization of public resources destined to research and development (R\&D). Through edicts, the FAPs describe models of research projects that could be funded with a given resource, and the specific purposes to which they are destined. Generally, such programs are oriented to a given sector, and addressed by one or more lines of Federal Government Pluriannual Programs. The FAPs funds are also destined to attend for local development demands, attracting research groups about the subjects listed in the edicts.

In a word, the FAPs facilitate the access of R\&D institutions installed at Amazonia, to public funds addressed to ST\&I. Currently, there are in the Brazilian Amazonia region eight $(\mathrm{N}=8)$ FAPs, according to Figure 4.

Such foundations possess research scholarship programs in modalities capacitating since the middle school (the 'Jovem Cientista Amazônida' prize - FAPEAM), Program of Junior Scientific Initiation Scholarships (FAPESPA, FAPEAM, and FAPEMA), and even programs for fixation of Senior doctors in the region.

The edicts launched by FAPs stimulate as the ICTs, as the entrepreneurial segments related to Subjects. Examples of such edicts are the 'Thematic Edicts' and the 'Program for Regional Scientific Development' (Programa de Desenvolvimento Científico Regional - PCR), specific for the necessities of every Amazonian state. The edicts supported by the federal government can be of the following types: Support to Biofuels (BIOCOM/FAPEAM, Maranhão Biodisel/FAPEA$M A)$; Support to health area, stimulating the promotion of research in the Unified Health System (Sistema Único de Saúde - SUS) (Edict PPSUS).

The other sector supported by FAPs' edicts was that of software and informatics one, with the 2010 Professional Award for Software Navegapará, from the Foundations for Support to Research of the State of Pará (Fundação de Amparo à Pesquisa do EStado do PArá - FAPESPA). Every edict presents some context differentiated and explained in the body of text. An example is the Edict CESMAT of FAPEAM, coming from a complementary adjustment of the Technical and Scientific Cooperation Agreement between Brazil and France (BRASIL/DOU, 22/ I / I 982), by exchange of verbal notes between the National Council for Scientific and Technological Development (CNPq) of Brazil and the "Centre d'Etudes Supérieures des MATières Premières" (CESMAT) of France.

There are also edicts contemplating the development and participation in national and international scientific events, such as: Program for Support to Development of Scientific and Technological Events (Programa de Apoio à Realização de Eventos Científicos e Tecnológicos - PAREV/ FAPEAM/FAPESPA), the Program for Support to development of Scientific, Technological, and Innovation Events (Apoio à realização de Eventos Científicos, Tecnológicos e de Inovação - AREC/FAPEMA), the Program for Assistance to Participation in Scientific Events (Auxílio à Participação em Eventos Científicos - APEC/FAPEMA), the Program for Support to Participation in Scientific and Technological Events (Programa de Apoio à Participação em Eventos Científicos e Tecnológicos - PAPE/FAPEAM), and the Program for Support to Development of ST\&I Events in the Grade School (FAPESPA).

The investigations and actions in the sectors of biotechnology are indirectly contemplated, within the programs stimulating the research in the entrepreneurial ambit, such as: the Program for Support to Research in Enterprises (Programa de APoio à Pesquisa em Empresas - PAPPE/FAPEAM), Integrated Program for Scientific and Technological Research (Programa Integrado de Pesquisa Científica e Tecnológica PIPT/FAPEAM), the Edict INOVA (from FINEP and the FAP of Tocantins state), the Program for Technological Diffusion to Micro and Small Enterprises (Micro e Pequenas Empresas - MPE), and the Program for Support to Research Network in Biocosmetic Agents (REDE de Pesquisas em BIOcosmético - REDEBIO).

Amazonas was the State pioneer in the implementation of the State Law of Innovation (\# 3095/2006), which enabled the launching of PAPPE Subvention Edict, which invested the amount of $\mathrm{R} \$ 6$ millions in Regional Micro and Small Enterprises for the development of product in the areas of Local Productive Arrangements (Arranjos Produtivos Locais APLs): handicraft; Brazil nuts; shipbuilding; phytotherapeutic and phytocosmetic agents; manihot starch and flour; wood, furnishing, and artifacts; ceramic-potter pole; pulp, extracts, and concentrates of regional fruits; fish production; environmental products and services; and ecologic and rural tourism (Amazonas Ciência, 2007;AMAZONAS/FAPEAM, 2008). So, the Amazonian investigators elaborate research projects

ISSN: 07 I8-2724. (http://www.jotmi.org)

Journal of Technology Management \& Innovation (c) Universidad Alberto Hurtado, Facultad de Economía y Negocios. 
and submit them to the public fund system of ST\&I, according to edicts guidelines.

Between the Amazonian FAPs, FAPEAM, FAPEMA, and FAPESPA were those that most invested and created new programs, during the period of analysis of this study. The programs created by these FAPs are, in general, very similar, as in terms of structure, as in the quality of their content. There are peculiarities between these programs, which follow specific political/administrative interests of every State.

\section{Patents}

The conversion of funded investigations into technological inventions was analyzed only, for the State obtaining the larger amount of public funds destined to ST\&l, as described in this study methodology. In this case, we analyzed the patent applications coming from institutions settled in the State of
Amazonas, filed at INPI. In this way, I 53 patent applications were identified. Out of these deposits, eighty five $(n=85)$ came from Enterprises, forty two $(n=42)$ from Natural Persons, eight $(n=8)$ from Foundations, sixteen $(n=16)$ from Research Institutes, and two $(n=2)$ from Public State Institutions not related to research [Fire brigade, for instance]. The percents of such patent applications, per type of institution, are described at Figure 5.

The larger part of patent applications ( $N=85$ deposits) was filed by enterprises installed in the State of Amazonas. According to Cruz (1999), among other authors, the enterprises are crucially important for a nation's technological innovation, as within the enterprises are effectively developed the new technologies, which will result in marketable goods. According to this logic, the enterprises represent a technological development locus, which will be accessed by population, to obtain products and services.

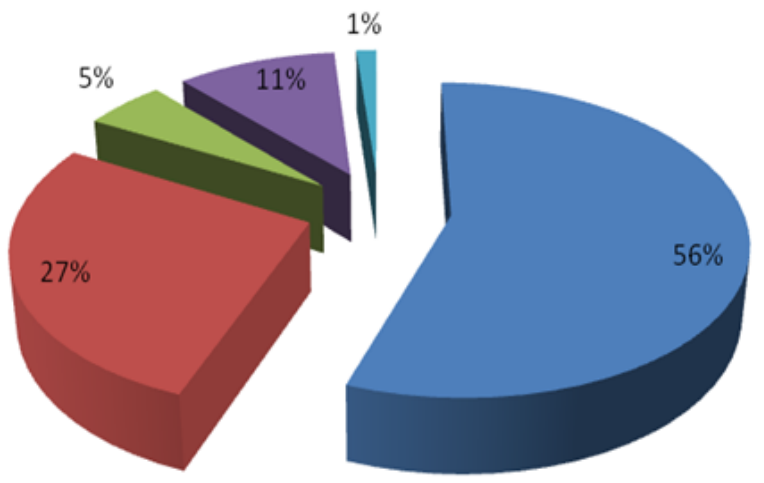

घEnterprise $\quad$ Natural Person $=$ Foundation $=$ Research Institution $=$ Public State Institution

Figure 5: Institutional distribution of patent applications coming from the state of Amazonas, in the period between 2003 and 2008.

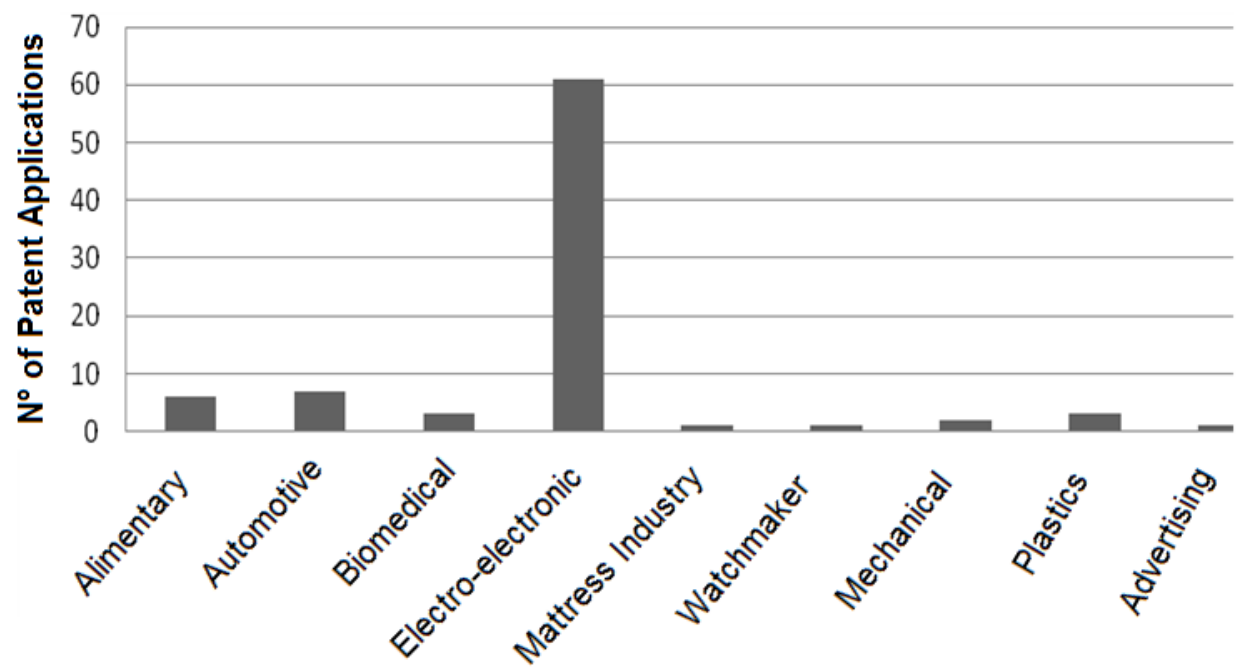

Figure 6: Frequency of patent applications deposited in the period between 2003 and 2008, coming from the State of Amazonas, executed by their respective industrial sector.

ISSN: 07I 8-2724. (http://www.jotmi.org) 
The larger part of patent applications ( $N=61$ deposits) came from entrepreneurial sectors of the Manaus Industrial Pole (PIM). At PIM, several national companies of the electro-electronic sector are inserted, as for instance, 'Nokia do Brazil Tecnologia LTDA.,'’Philips da Amazônia Indústria Eletr. LTDA.,' 'Samsung Eletromecânica da Amazônia LTDA.,'‘Semp Toshiba Amazonas LTDA.','Panasonic da Amazônia S/A.','Sony da Amazônia LTDA., 'LG Eletrônicos da Amazônia LTDA.', 'Gradiente Eletrônica S.A., 'Sharp do Brasil S/A', 'CCE Indústria e Componentes de Eletroeletrônicos', 'Grupo Itautec', 'Philco', and 'PST Indústria Eletrônica da Amazônia Ltda.'.

The PIM structure is attractive for the entrepreneurial sector of electro-electronics, a fact that demonstrates that the political actions, taken about 50 year ago, to induct the formation of 'Manaus Industrial Pole' were critical to develop and consolidate the electro-electronic sector in the region. This was due to the fact that the city of Manaus, capital of Amazonas state, did not possess a natural vocation for this sector. The creation of PIM was a governmental action strategically induced by free-trade policies for importation and exportation, and special tax incentives (SUFRAMA, 2003). This is the motive by which the State of Amazonas, currently, has its economy based on the sector of electro-electronics. The data presented at the figure 6 clearly show that patent applications, in this specific case, would be good indicator of Amazonian technological development.

However, the patent applications from sectors that are, apparently, part of the regional Amazonian vocations, as directly associated to utilization of the local biodiversity, were only incipient. The biomedical sector, for instance, counted only on three deposits $(\mathrm{N}=3)$, and the alimentary sector, with just six $(\mathrm{N}=6)$. However, the low number of deposits could indicate the starting of development in these sectors at Brazilian Amazonia, as can be observed at Figure 6 .

The data raised in this study demonstrate that the ICTs of Amazonas State were responsible for II\% of the patent applications ( $N=16$ deposits). These applications were filed by the National Institute of Amazonian Research (Instituto Nacional de Pesquisas da Amazônia - INPA) and by the Genius Institute of Technology (Genius Instituto de Tecnologia). The larger part of Amazonian ICTs develop investigation about the regional natural resources, and $60 \%$ of research scholarships offered by FAPEAM are addressed to biological areas. There is an interaction between ICTs and the PIM technological industries.

The Amazonas State has been looking for new economic forms of local development, conciliating the scientific experience of ICTs to entrepreneurial experience from PIM. The INPA, for instance, in the year of 2005, deposited four (04) patent applications titled: (I) "Species-specific method for determination of Leishmania (Viannia) guyanensis", (2) “Productive process for obtainment of dehydrated products from the utilization of pupunha flour (Bactris Gasipaes Kunth)",(3) "Instantaneous dehydrated soup of piranha and cream soup of piranha", (4) "Fermentative process of the production of pupunha alcoholic beverage". During this same period, the INPA was an active participant of the North Network of Intellectual Property, Biodiversity, and Traditional Knowledge (Rede Norte de Propriedade Intelectual, Biodiversidade e Conhecimento Tradicional - RNPIBCT), which aggregated several actors from the Manaus Free-trade Zone Authority (SUFRAMA), such as Center for Analysis, Research, and Technological Innovation Foundation (Fundação Centro de Análise, Pesquisa e Inovação Tecnológica - FUCAPI), and the Center of Biotechnology of Amazonia (CBA).

The Brazilian Amazonia ICTs participate in different research networks including states from other Brazilian regions, and even other countries. Such partnerships are important, as they enable the experience interchange between institutions developing research and biotechnological innovation with Amazonian plants, and the transference of technologies as well.

In contrast, the micro and small bioproducts enterprises are establishing relationships with the regional laboratories. The Laboratory of Consultancy and Quality Control Ltd. (Laboratório de Consultoria e Controle de Qualidade Ltda. - CQLAB) and the Center of Biotechnology of Amazonia (CBA) aggregate investigators from Amazonian ICTs, working in the local biotechnological sector, for the production of scientific knowledge able to be applied to regional biotechnological demands. Concomitantly, the Manaus Free-trade Zone Authority (SUFRAMA), linked to the 'Development, Industry, and International Trade Ministry' (Ministério do Desenvolvimento da Indústria e Comércio Exterior - MDIC), has promoted the development of Business Incubators and Poles of Micro and Small Enterprises focused on the utilization of regional supplies in their products.

In the practice, such initiatives are supported by the local government, by means of FAPs funding. However, the Amazonian enterprises possess difficulties to accomplish all determinations from institutions that regulate the Brazilian marketing, such as: the National Agency of Health Surveillance (Agência Nacional de Vigilância Sanitária - ANVISA), the Ministry of Agriculture, Livestock, and Supplying (Ministério da Agricultura, Pecuária e Abastecimento - MAPA), and the Ministry of Environment (Ministério de Meio Ambiente - MMA).

It is important to highlight that in Brazil, the university-enterprise partnership is not a simple process. The academic investigators possess difficulties to understand the entrepreneurial logic, while the entrepreneurs have difficulties to 
accomplish the scientific validation methods (Frickmann \& Vasconcellos, 2010). Even with such dichotomy, these partnerships should be continuously stimulated by the induction of edicts launched, as by FAPs, as by the aforementioned national fomentation agencies (FINEP, CNPq, CAPES, and BNDES).

The second larger part of patent applications coming from the State of Amazonas and raised in this study, was filed on behalf of Natural Persons ( $N=42$ applications), that is, independent inventors unlinked to ICTs. The smaller part was deposited by Foundations ( $N=8$ applications) and Public Institutions without scientific and technological research purposes ( $\mathrm{N}=2$ applications).

Adjustments to Amazonian innovation model are essential to amplify the impulses for production of regional bio-products at PIM.This way, a new production feature, based on the regional natural vocations well founded in the biodiversity, could be summed to the already consolidated and job-creator line of electro-electronics, which is currently generating innovation and income.

For the development of the biotechnology and general bioproducts sectors, a worry with environmental impacts minimization and a clear and objective legal structure should be aligned, allowing the enterprises to accomplish all the steps related to access to genetic resources, research, and production with the due juridical safety.

One of the legal impasses for the development of bio-products looks to be the lack of clarity on the part of governors, respecting to the union of innovative themes, such as biotechnology and the intellectual property of the Amazonian traditional knowledge. The knowledge, mapping, and access to databases about such potential are elemental for the conservation and appreciation of genetic resources, by the XXI century Brazil.

Currently, the research and access to biodiversity, as for investigation purposes, as for technological development targets, are regulated by the Provisional Measure (\#2186-16) of 2001 , which created the requirement of benefits distribution, in case of access to traditional knowledge associated to genetic resource. The major problem of this MP (\# $2 / 86 / 16$ ) is the lack of plausible and clear criteria, to enable the involved society to share the benefits resulting from the access to biodiversity. In this process, the MP (\# 2/86/16) opens gaps for numberless and debatable responses.

In parallel, the City of Manaus, located at Brazilian Amazonian center, was pointed by Becker (2009b) as a 'Global City', that is, a territorial unit articulating the contemporary economic expansion. For the development of Amazonian origin technologies, more incentives and studies are neces- sary, in order to: (I) amplify the Brazilian experience with Amazonian biotechnological employment; (2) improve the market strategies for insertion of Amazonian bio-products at a fair price, in the national and international markets; (3) attract middle and large size biotechnological industries; (4) apply the biosafety norms to avoid genetic contamination, as Amazonia is one of the most important global ecosystems; (5) promote more ICTs-Enterprises partnerships; (6) map the Amazonian supplies chains; and (7) reinforce the political induction mechanisms, comparing them to public policies implemented for the formation of Manaus Free-trade Zone. In terms of Brazilian health market, the Unified Health System (SUS) has currently created the 'National Listing of Medicinal Plants of Interest for SUS' (RElação Nacional de Plantas Medicinais de Interesse do SUS - RENISUS), containing 7I species of medicinal plants occurring in the Brazilian territory.About 15\% of these species are endemic of Amazonia; so, the production of monographs about the medicinal potential of such Amazonian flora species should be stimulated. In parallel to regional biotechnological development, several sustainable productive activities are being supported, with the purpose to assure the sustainable use of Amazonian resources (GIZ, 20I2). The environmental services, for instance, are utilized as a form to appraise the Amazonian conservation as a natural capital unit at the service of humanity (Young \& Fausto, 1998). However, the 'Ecologic Economic Macro Zoning of Legal Amazonia' (BRASIL/ZEE, 20I0) indicates alert points of this market, which are: $(I)$ the use of environmental services is defined by the international financial market as privilege to carbon capture transformed into commodity; (2) the market establishes a low price for the ton of CO2 (in 2008), as is also the case for the remaining commodities without value aggregation; (3) while the European formal market pays $€ 27.55$ for $\mathrm{CO} 2$ ton, the Chicago parallel market pays only US\$6.50 per CO2 ton (in 2008), and the latter one ends up being the most utilized; (4) the inclusion of compensations to stand upright the Amazonian forest could cause a decrease of $\mathrm{CO} 2$ price, facing the perceptible offering increase.

So, Brazil needs to find quickly safe and sustainable means to make viable the Amazonian biotechnological researches by the local institutions, becoming possible to accelerate the formation of human resources for the sector of Amazonian biotechnology and expand the portfolio of new Amazonian bio-products in the national and international market. For such, it is indispensable to assure the sustainability and socioeconomic inclusion for the agents of this chain base, who generally are the extractive traditional populations. Studies about economic, social, and environmental sustainability are necessary, as well as a higher impulse for the regional, national, and international cooperation to obtain the resolution of existing scientific bottleneck. 


\section{Conclusion}

In the last years, the financial stimulations to technological innovation at Brazilian Amazonia have increased. Moreover, new legislation with the purpose to establish higher synergy between ICTs and Amazonian enterprises has been created. Such stimulations were critical for the strengthening of short and long term S\&T actions in the region. Strategic projects were encouraged, as well as partnerships between institutions such as: INPA, EMBRAPA, FIOCRUZ, SUFRAMA, State Secretariats, Universities, Research Centers, among others. The launching of specific edicts such as PIPT and PAPPE fomented the innovation in regional micro and small enterprises. The national legal and political impediments over the biotechnological research at Brazilian Amazonia hamper the legal access to natural resources that are obtained by commodities values. In parallel, Amazonia still produces few innovations in bio-products productive sectors [utilize as supplies, plant resources from regional origin]. The lack of industries of these sectors settled in the region could be a cause for this phenomenon, as the public investments in Amazonian research, development, and innovation (RD\&l) have increased.

The application of such resources contributes for the expansion of the Amazonian scientific knowledge frontier, opening so new possibilities for sustainable and innovative investments, breaking a noxious cycle of unsustainable exploration of deforestation, and putting into effect the "sustainable use of biodiversity" [one of the targets of the Convention on Biological Diversity, ratified by Brazil in 1993]. The funding in ST\&I were decentralized in the last years, by means of Foundations of Support to Research (Fundações de Amparo á Pesquisa - FAPs). However, the increase of funded resources was still insufficient to become the innovation in bio-products sector a competitor of the incentives for the electroelectronics sector, as can be observed in this present study. The patent applications involving the local biodiversity arose, mainly, from the National Institute of Amazonian Research (INPA). The still incipient integration between ICTs and regional enterprises makes that the science produced at ICTs differentiate from the technological needs of local productive sector. The main ICTs settled at Amazonia investigate themes related to tropical rainforest, such as FIOCRUZ, the Tropical Medicine Foundation (FMT), the INPA, and the Emilio Goeldi Paraense Museum (Museu Paraense Emilio Goeldi - MPEG), but the local productive sector is still strongly driven by the electro-electronics enterprises installed at Manaus Industrial Pole (PIM).

The permanence of tax incentives to PIM is critical, and is not dependent on the technoscientific and economic arrangement of bio-products sector. The attraction of middle and large sized enterprises making use of regional natural sup- plies and interchanging experience with the regional micro and small enterprises could stimulate the organization and growth of productive chains based on traditional extractive activities. Such process should be conducted under strong governance strategies, mainly of local order, which are able to guide the entrepreneurial activities, without become their development impracticable. Hence, the biotechnological innovation axis should be continuously stimulated, in order to assure along the next 30 years, another front of sustainable development for the XXI Century Brazilian Amazonia.

\section{Acknowledgements}

To Suzanne de Oliveira Rodrigues Schumacher for her availability and the Foundation of Support to Research of the State of Amazonas (Fundação de Amparo à Pesquisa do Estado do AMazonas - FAPEAM) for the PhD scholarship provided to the first author.

\section{References}

ALBAGLI, S.. 200I. Biodiversidade, pesquisa e desenvolvimento na Amazônia. Amazônia: fronteira geopolítica da biodiversidade. Parcerias estratégicas, $\mathrm{n}^{\circ} .12$.

AMAZONAS/FAPEAM. 2009. Relatório de Gestão 2009. Manaus/AM. 79p.

ARRUDA, A. C.. 2009. Rede de inovação de dermocosméticos na Amazônia: o uso sustentável de sua biodiversidade com enfoques para as cadeias produtivas da castanha-dopará e dos óleos de andiróba e copaíba. Parc. Estrat. BrasiliaDF. v. I4, n. 29, p. 145-I72.

BECKER, B. K.. 2009a. Problematizando os Serviços Ambientais para o Desenvolvimento da Amazônia. Uma Interpretação Geográfica. In: Um projeto para a Amazônia no século 21: desafios e contribuições. Centro de Gestão e Estudos Estratégicos - CGEE. Brasília. Pp: 87-I28.

BECKER, B. K.. 2009b.Uma visão de futuro para o coração florestal da Amazônia. In: Um projeto para a Amazônia no século 21: desafios e contribuições. Centro de Gestão e Estudos Estratégicos - CGEE. Brasília. Pp: 38- 86.

BEUZEKOM B, Arundel A.. 20I I. Oecd biotechnology statistics. (http://www.oecd.org/dataoecd/5I/59/367602/2. pdf\#search=\%22OECD\%20Biotechnology\%20Statistics-2006\%22 (acessado em 04 de julho de 20I I).

BRASIL/ LEI N 10.973 de 02 de dezembro de 2004. Dispõe sobre incentivos à inovação e à pesquisa científica e tecnológica no ambiente produtivo e dá outras providências. Brasília, 2 de dezembro de 2004; 1830 da Independência e II60 da República.

ISSN: 07 I8-2724. (http://www.jotmi.org)

Journal of Technology Management \& Innovation (c) Universidad Alberto Hurtado, Facultad de Economía y Negocios. 
BRASIL/MAPA. 2009. Curso de Propriedade Intelectual \& Inovação no Agronegócio. Capítulo I. Ministério da Agricultura, Pecuária e Abastecimento-MAPA. IBSN: 978-857426-070-9.página 4I.

BRASIL/MCT. 2009. Ciência, Tecnologia e Inovação para a Amazônia. Ministério da Ciência e Tecnologia. 5 Ip.

BRASIL/MMA. 2010. Macro Zoneamento Ecológico Econômico da Amazônia Legal: estratégias de transição para sustentabilidade. Proposta Preliminar para Consulta Pública. Ministério do Meio Ambiente. Brasília, 164p.(http://www. mma.gov.br/estruturas/225/_arquivos/macrozee_proposta_preliminar_para_consulta_26_jan_225.pdf) acessado em 04 de fevereiro de 2010.

BRASIL/PAS. 2008. Plano Amazônia Sustentável: diretrizes para o desenvolvimento sustentável da Amazônia brasileira. Presidência da República. - Brasília: MMA, I I2p. P: 47.

BRASIL/SUDAM. Amazônia Legal: área de atuação/ situação geográfica. Superintendência do Desenvolvimento da Amazônia, Ministério da Integração $\mathrm{Na}$ cional. Presidência da República.-Brasília. (acessado em 16/08/ 2010) http://www.redegoverno.gov.br/defaultCab. asp? idservinfo $=356 \mid$ | \& \&url=http://www.ada.gov.br/index. php?option=com_content\&task=category\&sectionid=9\&id $=54 \&$ Itemid $=5$ I

CGEE. 20I0. Doutores 2010: estudo da demografia da base técnico-científica brasileira. Brasília, DF. CGEE, 508p.

CLEMENT, C. R. \& Higuchi, N..2006.A Floresta Amazônica e o Futuro do Brasil. Cienc. Cult. [online].V. 58, n. 3, pp. 44-49. ISSN 0009-6725.

COSTA,W. M. 2009.A utilização dos recursos florestais nãomadeireiros. In: Um projeto para a Amazônia no século 21: desafios e contribuições. Centro de Gestão e Estudos Estratégicos - CGEE. Brasília.

CRUZ, C. H. B. A.. 1999. A universidade, a empresa e a pesquisa que o país precisa. Revista Humanidades, UnB. 45, pp. 15-29.

ENRÍQUEZ, G. 2009.Amazônia - Rede de Inovação de Dermocosméticos: Sub-rede de dermocosméticos na Amazônia a partir do uso sustentável de sua biodiversidade com enfoques para as cadeias produtivas da castanha-do pará e dos óleos de andiroba e copaíba. Parcerias Estratégicas. Cento de Gestão de Estudos Estratégicos - GEEE.V. I4, N. 28, jun, Pp. 5 I-II8.
FRICKMANN, F. dos S. e S.,Vasconcellos,A. G. 2010. Oportunidade para a inovação e aproveitamento sustentável da biodiversidade amazônica em bases sustentáveis. Revista T\&C Amazônia. Ano VIII - Nº. 19. Pp. 20-28. https://portal.fucapi. $\mathrm{br} / \mathrm{tec} / \mathrm{artigos}$.php

FRICKMANN, F. S. E. S.; Vasconcellos, A. G. 20II. Research and patent of phytotherapeutic and phytocosmetic products in the brazilian Amazon. Journal of Technology Management \& Innovation. v.6, p.I36-I50, ISSN/ISBN: 07/82724. Homepage: http://www.jotmi.org/index.php/GT/article/view/ art226/660.

GIZ. 2012. Oportunidades de Apoio a Atividades Produtivas Sustentáveis na Amazônia- Subsídios para debate. 200p.

GOTTLIEB, O.R. \& Borin, M.r.m.b. 2002. Shamanism or science? Anais da Academia Brasileira de Ciências, 74(I):135144.

HOMMA, A. K. O.. 2008. Extrativismo, Biodiversidade e Biopirataria na Amazônia. Texto para Discussão 27. Embrapa Informação Tecnológica, Brasília/DF. I0 I p.

JORNAL DA CIÊNCIA. 2009. Estados buscam amparo para pesquisa científica e tecnológica. Sociedade Brasileira Para o Progresso da Ciência. ANO XXIII, N. 64I Rio de Janeiro, 3 de abril ISSN I4I4-655X.

KRUGMAN, P. R.. 2009. A Crise de 2008 e a Economia da Depressão. Tradução Afonso Celso da Cunha Serra. Rio de Janeiro : Elsevier, $-3^{\mathrm{a}}$. Reimpressão.

LIMA, F. D., Giesbrecht, H. O., E Lima, S. U.. 2007. Indicação Geográfica: agregação de valor aos produtos amazônicos. T\&C Amazônia, Ano V, Número II.

MOREIRA, E. \& Mileo, P. B.. 2003. Os impactos da concessão de marcas e patentes relativas á biodiversidade amazônica no âmbito das relações de comércio exterior do Estado do Pará. Relatório apresentado á Secretaria de Indústria, Mineração e Comércio do Estado do Pará. Núcleo de Propriedade Intelectual, Grupo de Pesquisa sobre patentes biotecnológicas. Centro Universitário do Pará - CESUPA. I76p.

REVILLA, J.. 2007. Mapeamento da Biodiversidade Amazônica: potencialidade dos fitos. T \& C Amazônia, Ano V, N. I I, Jun. I8- 25.

SANTILLI, J. 2005. A proteção jurídica dos conhecimentos tradicionais. In: O direito e o desenvolvimento sustentável: curso de direito ambiental/ Organizador: Aurélio Virgílio Veiga Rios. São Paulo, Peirópolis; Brasília - DF: Instituto Internacional de Educação do Brasil - IEB. ISBN: 85-7596-05 I - 2. 4 I Ip. Pp: 75-85.

ISSN: 07 I8-2724. (http://www.jotmi.org)

Journal of Technology Management \& Innovation (c) Universidad Alberto Hurtado, Facultad de Economía y Negocios. 
SILVEIRA, J. M. F. J. da, Borges, I. De C., Fonseca, M. da G. D.. 2007. Biotecnologia e Desenvolvimento de Mercados: Novos Desafios, Novos Conceitos? In: Dimensão do Agronegócio Brasileiro: Políticas, Instituições e Perspectivas. Pp: 3 | 8-357.

SILVEIRA, J. M. F.J. da \& Borges, I. C de. 2004. Um Panorama da Biotecnologia Moderna. In: Biotecnologia e recursos genético: desafios e oportunidades para o Brasil/ organizado por José Maria Ferreira Jardim da Silveira, Maria Ester Dal Poz, Ana Lúcia Assad. Campinas/SP: Instituto de Economia/ FINEP.

SUFRAMA. 2003. Zona Franca de Manaus: interiorizando o desenvolvimento no interior do Estado. Ministério do Desenvolvimento, Indústria e Comércio Exterior - Superintendência da Zona Franca de Manaus - SUFRAMA. Amazonas. Pg.I I. 190p.

VASCONCELLOS, A. G. \& Rodrígues, R. L.. 2003. Potencial de inovação e patenteamento de fitoterápicos no Brasil: considerações à luz da legislação de acesso ao patrimônio genético e ao conhecimento tradicional associado. Resumos de Trabalhos da $V$ Jornada Catarinense e I Jornada Internacional de Plantas Medicinais. 8 a 12 de maio de 2006, Joinville, SC, Brasil.

YOUNG, C. E. F. \& Fausto,J. R. B.. 1998.Valoração de recursos naturais como instrumento de análise da expansão da fronteira agrícola na Amazônia. Instituto de Pesquisas. 